\title{
Electricity Demand Prediction of Beijing during the 13th Five-year
}

\author{
Na-na Li, Hui-ru Zhao, Ming-rui Zhao \\ School of Economics and Management, North China Electric Power University, Beijing, China \\ Email address: \\ nancyli1007@163.com (Na-na Li)
}

\section{To cite this article:}

Na-na Li, Hui-ru Zhao, Ming-rui Zhao. Electricity Demand Prediction of Beijing during the 13th Five-year. International Journal of Energy and Power Engineering. Special Issue: Current Energy Issues in China. Vol. 4, No. 4-1, 2015, pp. 12-16.

doi: $10.11648 /$ j.ijepe.s.2015040401.13

\begin{abstract}
With the emergence of a "new economic norm" and the development of "economic integration in Beijing, Tianjin and Hebei", electricity demand situation in Beijing will change significantly in the future. To guide the planning and construction of power grid in Beijing, it is indispensable to predict electricity demand during the 13th Five-year. Since the factors and affecting mechanisms for electricity demand are different in different sectors, the total electricity consumption in this paper is divided into five parts: the first industry, industry, construction industry, the tertiary industry and resident sectors. The exponential smoothing method and co-integration theory are introduced to establish the forecasting model of electricity demand in different sectors. Therefore, based on the forecasting model and scenario analysis, the analysis results show that the total electricity consumption will grow at an annual rate of 4.9\%-6.0\% during 13 th Five-Year-Plan period, and the consumption would reach more than $0.1397 \times 1012 \mathrm{kWh}$ in 2020 .
\end{abstract}

Keywords: Electricity demand, forecasting, subsectors, Exponential smoothing method, co-integration theory

\section{Introduction}

Electricity production and supply, as the foundation of national economy, provides an essential condition for economic and social development, and the improvement of living standard. The incompatibility between electric industry and economic development may put negative impact on the national economy and people's life[1-2]. Therefore, in the electric power market, the balance of demand and supply is one of the most important problem attracting stakeholders from many aspects. Meanwhile, with the emergence of a "new economic norm" and the development of "economic integration in Beijing, Tianjin and Hebei", the electricity demand situation in Beijing will change significantly in the future. [3]. On this basis, combing the economic development planning and the goal of economic structure adjustment, the electricity demand in Beijing during 13th Five-Year-Plan period is important to ensure the harmonious development between electricity industry and economy development [4].

In order to fully reflect the characteristics of each industry and the effect of the economic structure adjustment, the whole society electricity demand in this paper is divided into five parts: the first industry, industry, construction industry, the tertiary industry and resident sectors. According to the influencing factors of each sector for electricity demand, the demand forecasting model of each sector is establish. In addition, the whole society electricity demand equates to the sum of the demand of five sectors. The whole society electricity demand based on subsectors can fully consider the influencing factors in different sector respectively, which can better control the prediction error and make the prediction more accurate.

\section{Research Methods}

\subsection{Exponential Smoothing Method}

Exponential smoothing is one of time series prediction method which has been used widely. It combines the advantages of period average and moving average. This method does not discard the past data, which gradually weakened the influence of the past date, through the adjustment coefficients[5-6]. Exponential smoothing method can be divided into three categories: Single Exponential Smoothing, Double Exponential Smoothing and Holt-Winters. Different models can realize the prediction of 
different types of time series. In this paper, the Holt-Winters method is used to forecast the electricity demand of the first industry in Beijing.

The Holt-Winters method is similar with Double Exponential Smoothing, which is suitable to predict the time series with liner trend. The Holt-Winters method contains of two smoothing coefficient, namely $\alpha$ and $\beta(0 \leq \alpha, \beta \leq 1)$. The time series after smoothing $\hat{y}_{t}$ is shown as follows:

$$
\hat{y_{t+\tau}}=a_{t}+b_{t} \tau, \tau=1,2,3 \cdots
$$$$
\text { Where, } \begin{aligned}
& a_{t}=\alpha y_{t}+(1-\alpha)\left(\mathrm{a}_{t-1}+\mathrm{b}_{t-1}\right) \\
& b_{t}=\beta\left(\mathrm{a}_{t}-\mathrm{a}_{t-1}\right)+(1-\beta) \mathrm{b}_{t-1}
\end{aligned} ;
$$

$a_{t}$ represents the intercept and $b_{t}$ represents the slope, which are calculated based on the exponential smoothing.

The forecasting model based on the Holt-Winters method can be expressed as follows:

$$
\hat{y_{T+\tau}}=a_{T}+b_{T} \tau, \tau=1,2,3 \cdots
$$

Where, $\mathrm{T}$ is the last data of the time series and $\tau$ is the predict cycles.

\subsection{The Basic theory of co-Integration Theory}

Co-integration was firstly put forward by Granger in 1981. In this theory, if the linear combination of non-stationary time series is stable, there must be a co-integration relationship among these variables, namely these variables keep a long-term equilibrium relationship each other. Since the time series of economic and electric indicators are always not smooth, the co-integration theory is put forward to analyze the relationship between electricity demand and economic development in Beijing. Based on the Stationarity test and Johansen test, a long-term equilibrium model would be established to analyze the relationship between electricity demand economy. The specific steps are shown as follows:

(1) Stationarity test[7]

The ADF unit root test is a common method used to test the stability of a time series. The time series variable model is established as follows:

$$
\Delta X_{t}=\alpha+\beta+\delta X_{t-1}+\sum_{i=1}^{p} \theta \Delta X_{t i}+\varepsilon_{t}
$$

Where, $\alpha$ is constant, $\mathrm{t}$ is trend term, $\mathrm{p}$ is the optimal lag order number, $\varepsilon_{t}$ is random error term. For a given significance level, when the ADF test value is less than the critical value, the time series is stable.

(2) Co-integration test[8]

Co-integration can be expressed as follows: if $y t \sim \mathrm{I}(\mathrm{d})$, namely yt becomes stationary after $\mathrm{d}$ times differencing, there must exist $\alpha=\left[\alpha_{1}, \alpha_{2}, \ldots \ldots, \alpha_{k}\right] \quad$ makes
$Z_{t}=\alpha X_{t}^{\prime} \sim I(d-b)(b>0) . \quad$ On this basis, $X_{1 t}, X_{2 t}, \ldots ., X_{k t}$ is co-integration of $(d, b)$ order, namely $X_{t} \sim C_{I}(d, b)$, and $\alpha$ co-integrated vector.

The JJ (Johansen and Juselius) co-integration test is always used to test the co-integration for multiple variables. There are two ways to test the co-integration: TRACE and MAX are commonly two output results in this test.

\section{Forecasting Model of Electricity Demand in Each Sector}

(1) The prediction model of electricity demand for the first industry

The first industrial electricity consumption accounts for less, and the influencing factors are unstable. Therefore, the time series method is more suitable then the structural model to forecast the electricity demand of the first industry, namely the exponential smoothing method is adopted to infer the first industrial utilization situation based on the past information.

(2) The prediction model of electricity demand for industry

Considering the characters of the industry production, the value-added of industry $(G D P g)$, industrial proportion of heavy industry $(\mathrm{Mz})$, electricity consumption intensity of the industry (Eg) are the key factors affecting the electricity demand of the industry electricity demand ( $Q g$ ) [9-10]. Therefore, based on the unit root test and co-integration test of these four factors, the forecasting model is established as follows:

$$
\ln Q g=0.9955 \ln G D P g+5.1338 E g-2.8214
$$

Since the coefficients of above forecasting model has been through the inspection, there is a long-term equilibrium correlation among $\ln Q g, \mathrm{GDPg}, \mathrm{Mz}$ and $\mathrm{Eg}$. From the perspective of long-term equilibrium, when the added-value of industry increases $1 \%$, the electricity demand increase $0.9955 \%$; when industrial proportion of heavy industry increase $1 \%$, the electricity demand increases $0.03 \%$; when electricity consumption intensity of industry increases $1 \mathrm{kWh} /$ ten thousand yuan, the electricity demand increases $0.51338 \%$.

(3) The prediction model of electricity demand for the construction industry

The value-added of construction industry ( $G D P j$ ), construction power efficiency $(E j)$ are the key factors affecting the electricity demand of the construction industry electricity demand ( $Q j$ ) [11]. Therefore, based on the unit root test and co-integration test of these four factors, the forecasting model is established as follows:

$$
\ln Q j=0.98 \ln G D P j-0.04 E F j-1.96
$$

Since the coefficients of above forecasting model has been through the inspection, there is a long-term equilibrium correlation among $\ln Q j, \ln G D P j$ and $E j$. From the perspective of long-term equilibrium, when the added-value 
of construction industry increases $1 \%$, the electricity demand increases $0.98 \%$; when construction power efficiency increases $1 \%$, the electricity demand decrease $0.04 \%$.

(4) The prediction model of electricity demand for the tertiary industry

The value-added of the tertiary industry ( GDP3), the level of the resident consumes $\left({ }_{R C L}\right)$ are the key factors affecting the electricity demand of the tertiary industry electricity demand (Q3)[12].Therefore, based on the unit root test and co-integration test of these four factors, the forecasting model is established as follows:

$$
\ln Q 3=-3.9880+0.9991 \ln G D P 3+19.2356 E 3
$$

Since the coefficients of above forecasting model has been through the inspection, there is a long-term equilibrium correlation among $\ln Q 3$ and $\ln G D P 3$. From the perspective of long-term equilibrium, when the added-value of tertiary industry increases $1 \%$, the electricity demand increases $0.37 \%$; when the level of the resident consumes increases $1 \%$, the electricity demand increases $0.62 \%$.

(5) The prediction model of electricity demand for the resident sector

The households $(H)$, the level of the resident consumes ( $R C L$ ) and the maximum temperature $(H T)$ are the key factors affecting the electricity demand of the resident sector electricity demand ( $Q p$ ) [13]. Therefore, based on the unit root test and co-integration test of these four factors, the forecasting model is established as follows:

$$
Q p=0.39 H+0.003 R C L+0.67 H T-165.08
$$

Since the coefficients of above forecasting model has been through the inspection, there is a long-term equilibrium correlation among $Q p, R C L, H$, and $H T$. From the perspective of long-term equilibrium, when the households increase 1 unit, the electricity demand of resident sector increases $0.39 \%$; when the level of the resident consumes increase 1 unit, the electricity demand of resident sector increases 0 . 003\%; when the maximum temperature increase 1 unit, the electricity demand of resident sector increases $0.67 \%$.

\section{Forecasting the Electricity Demand of Each Sector in Hebei Province}

\subsection{The Development Situation of each Influencing Factors}

According to the development planning of different sectors, the situation of each influencing factors during the $13^{\text {th }}$ Five-Year-Plan are shown as follows:

Table 1. The scenarios of influencing factors for forecasting the electricity demand in Beijing.

\begin{tabular}{llll}
\hline Influencing factors & year & $\begin{array}{l}\text { low } \\
\text { situation }\end{array}$ & $\begin{array}{l}\text { high } \\
\text { situation }\end{array}$ \\
\hline $\begin{array}{l}\text { Industrial added value } \\
\text { growth rate }\end{array}$ & $2014-2020$ & $5.00 \%$ & $6.00 \%$ \\
$\begin{array}{l}\text { Construction industrial added } \\
\text { value growth rate }\end{array}$ & $2014-2020$ & $11.00 \%$ & $12.00 \%$ \\
$\begin{array}{l}\text { Tertiary industry added value } \\
\text { growth rate }\end{array}$ & $2014-2020$ & $6.00 \%$ & $7.00 \%$ \\
$\begin{array}{l}\text { Growth rate of industry } \\
\text { power consumption for per }\end{array}$ & $2014-2020$ & $-2.00 \%$ & $-2.00 \%$ \\
$\begin{array}{l}\text { unit } \\
\begin{array}{l}\text { Growth rate of power } \\
\text { ffficiency for construction }\end{array}\end{array}$ & $2014-2020$ & $-2.00 \%$ & $-2.00 \%$ \\
$\begin{array}{l}\text { industry } \\
\begin{array}{l}\text { Level of the resident } \\
\text { consumes }\end{array}\end{array}$ & $2014-2020$ & $6.00 \%$ & $7.00 \%$ \\
$\begin{array}{l}\text { Growth rate of households } \\
\text { The highest temperature }\end{array}$ & $2014-2020$ & $0.08 \%$ & $0.10 \%$ \\
\hline
\end{tabular}

\subsection{The Forecasting Results of Electricity Demand in Each Sector}

According to each industry and residents electricity consumption forecasting model, and the development situations, the various industries and residential electricity demand are calculated. The detail results are shown in the table6.

\begin{tabular}{|c|c|c|c|c|c|c|}
\hline \multirow{2}{*}{ Scenarios } & \multicolumn{2}{|l|}{2015} & \multicolumn{2}{|l|}{2020} & \multicolumn{2}{|c|}{$\begin{array}{l}\text { Average annual growth rate during } \\
13^{\text {th }} \text { Five-year }\end{array}$} \\
\hline & $\begin{array}{l}\text { Low development } \\
\text { speed }\end{array}$ & $\begin{array}{l}\text { High development } \\
\text { speed }\end{array}$ & $\begin{array}{l}\text { Low development } \\
\text { speed }\end{array}$ & $\begin{array}{l}\text { High development } \\
\text { speed }\end{array}$ & $\begin{array}{l}\text { Low development } \\
\text { speed }\end{array}$ & $\begin{array}{l}\text { High development } \\
\text { speed }\end{array}$ \\
\hline \multicolumn{7}{|c|}{ Added-value (One hundred million yuan) } \\
\hline industry & 2384.73 & 2453.52 & 3043.59 & 3480.37 & $5.00 \%$ & $6.00 \%$ \\
\hline Construction industry & 1018.15 & 1074.70 & 1639.74 & 1893.99 & $10.00 \%$ & $12.00 \%$ \\
\hline \multicolumn{7}{|c|}{ Electricity demand (million $\mathrm{kWh}$ ) } \\
\hline First industry & 22.52 & 22.52 & 31.49 & 31.49 & $6.94 \%$ & $6.94 \%$ \\
\hline industry & 337.41 & 367.83 & 402.22 & 459.66 & $3.58 \%$ & $4.56 \%$ \\
\hline Construction industry & 27.18 & 28.66 & 40.11 & 46.20 & $8.09 \%$ & $10.02 \%$ \\
\hline Tertiary industry & 447.44 & 460.02 & 596.09 & 641.85 & $5.90 \%$ & $6.89 \%$ \\
\hline Residents demand & 178.27 & 185.71 & 218.00 & 243.90 & $4.10 \%$ & $5.60 \%$ \\
\hline
\end{tabular}

Table 2. Prediction results of added-value and electricity demand of each section in Hebei province. 
Table 3. Prediction results of economic structure and electricity demand structure

\begin{tabular}{|c|c|c|c|c|c|c|}
\hline \multirow{2}{*}{ Scenarios } & \multicolumn{2}{|l|}{2015} & \multicolumn{2}{|l|}{2020} & \multicolumn{2}{|c|}{$\begin{array}{l}\text { Annual proportion during } \\
13^{\text {th }} \text { Five-year }\end{array}$} \\
\hline & $\begin{array}{l}\text { Low Development } \\
\text { speed }\end{array}$ & $\begin{array}{l}\text { High development } \\
\text { speed }\end{array}$ & $\begin{array}{l}\text { Low Development } \\
\text { speed }\end{array}$ & $\begin{array}{l}\text { High development } \\
\text { speed }\end{array}$ & $\begin{array}{l}\text { Low Development } \\
\text { speed }\end{array}$ & $\begin{array}{l}\text { High development } \\
\text { speed }\end{array}$ \\
\hline \multicolumn{7}{|c|}{ Proportion of industry electricity demand in the whole society demand (\%) } \\
\hline First industry & $2.22 \%$ & $2.16 \%$ & $2.45 \%$ & $2.25 \%$ & $2.36 \%$ & $2.22 \%$ \\
\hline industry & $36.00 \%$ & $35.99 \%$ & $34.35 \%$ & $34.35 \%$ & $35.00 \%$ & $34.99 \%$ \\
\hline Construction industry & $44.18 \%$ & $44.06 \%$ & $46.28 \%$ & $45.94 \%$ & $45.46 \%$ & $45.20 \%$ \\
\hline Residents demand & $2.22 \%$ & $2.16 \%$ & $2.45 \%$ & $2.25 \%$ & $2.36 \%$ & $2.22 \%$ \\
\hline
\end{tabular}

\section{Conclusion}

Since the period between construction and production for the electricity project is very long, it is indispensable to make an accurate prediction for guiding a scientific planning, investment and construction. Therefore, under the current situation, in order to guarantee plentiful electricity supply during the 13th Five-year period, the electricity demand should be predicted exactly in Beijing, which is meaningful to promote the economic development and life standard improvement.

The characteristics of whole society electricity demand in Beijing during the $13^{\text {th }}$ five-year can be obtained based on the analyzed results of five sectors:

(1) The whole electricity demand will grow with a middle-low speed.

With the appearance of "new normal" and development of integration of Beijing-Tianjin-Hebei region, a large scale of industrial enterprises would be shift to other places, which will decrease the growth rate of electricity demand of industry. Moreover, with the strengthening of the energy saving and emission reduction in Beijing, the electricity consumption intensity decreased obviously. Therefore, on the basis, the whole electricity demand in Beijing would continue increasing with a middle-low speed. According to the forecasting results of electricity demand, the growth rate of the whole electricity demand would be $4.90 \%-6.00 \%$, which will decline $1.5 \%$ comparing the rate in the growth rate during the $12^{\text {th }}$ five-year.

(3) The electricity demand structure will change.

The integration of Beijing-Tianjin-Hebei region would transfer industries without capital function to other places. Therefore, the heavy industry enterprises and low-end services industry will be shifted. With the adjusting and optimizing of economic structure, the electricity demand structure would change. In the period of $13^{\text {th }}$ five-year, although the demand structure will keep the mode of "third, second, first", the proportion of the demand for tertiary industry will gradually rise, and the proportion of the second industry will decline. Meanwhile, the proportion of the first industry will keep stable proportion.

\section{Acknowledgments}

This study is supported by the Humanity and Social
Science project of the Ministry of Education of China (Project number: 11YJA790217), the National Natural Science Foundation of China (Project number: 71373076), the Fundamental Research Funds for the Central Universities(2015XS31), and Science and Technology Project of State Grid Corporation of China (Contract number: SGHB0000DKJS1400116).

\section{References}

[1] Elakrmi F, Shikhah N A. Electricity Demand Forecasting[J]. Business Intelligence in Economic Forecasting: Technologies and Techniques: Technologies and Techniques, 2010: 296.

[2] Yao A W L, Chi S C, Chen J H. An improved grey-based approach for electricity demand forecasting[J]. Electric Power Systems Research, 2003, 67(3): 217-224.

[3] Boqiang L. Structural changes, efficiency improvement and electricity demand forecasting $[\mathrm{J}]$. Economic Research Journal, 2003, 5: 7-9.

[4] Taylor J W, Majithia S. Using combined forecasts with changing weights for electricity demand profiling[J]. Journal of the Operational Research Society, 2000: 72-82.

[5] Gardner E S. Exponential smoothing: The state of the art-Part II $[\mathrm{J}]$. International journal of forecasting, 2006, 22(4): 637-666.

[6] Christiaanse W R. Short-term load forecasting using general exponential smoothing[J]. Power Apparatus and Systems, IEEE Transactions on, 1971 (2): 900-911.

[7] Xiaoping H, Xiying L, Yanping L. China's Electricity Demand Forecast under Urbanization Process [J][J]. Economic Research Journal, 2009, 1: 118-130.

[8] Yoo S H. The causal relationship between electricity consumption and economic growth in the ASEAN countries[J]. Energy Policy, 2006, 34(18): 3573-3582.

[9] Xie P, Tan Z, Hou J, et al. Analysis on dynamic relationship between urbanization and electricity consumption level in China[J]. Power System Technology, 2009, 33(14): 72-77.

[10] Ang B W. Decomposition methodology in industrial energy demand analysis[J]. Energy, 1995, 20(11): 1081-1095.

[11] Ozturk H K, Ceylan H. Forecasting total and industrial sector electricity demand based on genetic algorithm approach: Turkey case study[J]. International Journal of Energy Research, 2005, 29(9): 829-840. 
[12] Akay D, Atak M. Grey prediction with rolling mechanism for electricity demand forecasting of Turkey[J]. Energy, 2007, 32(9): 1670-1675.
[13] Narayan P K, Smyth R, Prasad A. Electricity consumption in G7 countries: A panel cointegration analysis of residential demand elasticities[J]. Energy policy, 2007, 35(9): 4485-4494. 